\title{
Willpower Is Overrated
}

Commentary of "Willpower With and Without Effort" by George Ainslie, BBS, 2020

Michael Inzlicht (University of Toronto) \& Malte Friese (Saarland University)

Michael Inzlicht

University of Toronto

Department of Psychology

1265 Military Trail

Toronto, Ontario M1C 1A4

Canada

Email: michael.inzlicht@utoronto.ca

Website: www.michaelinzlicht.com

Tel: 416-208-4826

Malte Friese

Saarland University

Department of Psychology

Campus A2 4

66123 Saarbrücken

Germany

Email: malte.friese@uni-saarland.de

Website: https://www.uni-saarland.de/friese

Tel: +496813023196

Commentary currently in press at Behavioral and Brain Sciences 


\begin{abstract}
Any analysis of self-regulation that focuses solely on willpower in conflict-laden situations is insufficient. Research makes clear that the best way to reach one's goal is not to resist temptations but to avoid temptations before they arrive; it further suggests that willpower is fragile and not to be relied on; and that the best self-regulators engage in willpower remarkably seldom.
\end{abstract}

Word Count Abstract: 60

Word Count Main Text: 983

Word Count References: 831

Word Count Total: 2,032 


\section{Willpower Is Overrated}

Ainslie analyzes the concept of willpower, which he defines as the process of foregoing small short-term rewards in favor of superior long-term rewards. Willpower, according to this view, entails cognitive conflict between two desires, typically with a passing temptation in conflict with some longstanding goal. Here, we submit that any analysis of goal-directed behavior that is restricted to such in-the-heat-of-the-moment cognitive conflict-no matter how fine-grained and valid - will inevitably miss an indispensable part of the self-regulatory process. Instead, we suggest that deeper insights can be gained by also focusing on the various psychological processes that occur well before facing a temptation. Our commentary thus focuses less on the details of Ainslie's proposal and more on what his proposal misses.

The disciplines of psychology, economics, and neuroscience presumably turned toward the scientific study of willpower because it appeared to predict a broad set of societally-important outcomes. Willpower, and the related concepts of self-control and self-regulation (Fujita, 2011; Inzlicht et al., 2021), predict all manner of good outcomes, including academic achievement, health, wealth, even criminal offending (Moffitt et al., 2011). Famously, 4 year old children who had superior willpower, as assessed by how long they could resist eating a marshmallow, grew up to be adolescents with better academic, social, and health outcomes that persisted into adulthood (Casey et al., 2011; Mischel et al., 1989; cf. Watts et al., 2018).

The implication of these sorts of prospective studies is clear: willpower is critical for the good life. Or, so it seemed.

The problem is that children who grow up to become well-adjusted adults might not achieve this feat only via willpower. In fact, the importance of willpower is unsettled. Other processes seem more critical. Research over the past decade makes clear that the best way to reach one's goals is not to fight temptations but to avoid them before they arrive. Research further suggests that willpower is fragile, and that the best self-regulators engage in willpower remarkably seldom.

The first clues that willpower may be overrated came from research examining people who appeared to be the best at meeting their goals. Such people have high trait self-control (Tangney et al., 2004) or high levels of trait conscientiousness (Roberts et al., 2014). What came as a surprise to many at the time was that these people used willpower remarkably infrequently in their daily lives, markedly less than people with low self-control (Hofmann, Baumeister, et al., 2012). Instead, it appeared that their self-regulatory abilities were related to the routinization of goal-directed behaviors and the cultivation of good habits (de Ridder et al., 2012; Galla \& Duckworth, 2015). Why might this be?

People high in trait self-control experience fewer desires that conflict with their longstanding goals; they experience fewer temptations, fewer and less pronounced cognitive conflicts (Hofmann, Baumeister, et al., 2012; Schneider et al., 2019). One reason for this is that effective self-regulators pursue goals because they truly feel like they want-to pursue them and not 
because they feel they have-to pursue them (Converse et al., 2019). That is, they come up with reasons to pursue their goals that feel autonomous and authentic and not reasons that feel like an imposition (Ryan \& Deci, 2000). Such want-to goals seem resistant to temptation, attracting fewer disruptive thoughts and emotions (even implicit ones) that might detract a person from meeting their goals (Milyavskaya et al., 2015).

Effective self-regulators avoid having to use willpower because they make plans that structure their lives to avoid temptation from arising. They are planful and future-oriented, drawing up comprehensive strategies that anticipate and deal with potential obstacles to bring their future goals about (Ludwig et al., 2018, 2019). They often recruit several simultaneous strategies to achieve their goals, many of which are considered proactive, occurring before a temptation is encountered (Hennecke et al., 2019). For example, people high in trait conscientiousness have better romantic relationships, in part, because they avoid situations and actions that can lead to infidelity (Hill et al., 2014).

By cultivating good habits, selecting personally meaningful goals, and avoiding temptation before it arises, effective self-regulators do not need to rely on willpower as often. And this is a good thing, as it is unclear whether willpower should be relied upon. Despite the controversy surrounding the empirical robustness of the concept of ego depletion (Friese et al., 2019), fatigue, and its downstream consequences on attention, is real (Hockey, 2013). It has long been known that attentional control cannot be sustained indefinitely (Mackworth, 1948). The result of such limits is that people become less able or less willing to sustain their resolve after bouts of effortful work (Blain et al., 2016; Lin et al., 2020), though such effects might be considerably smaller than previously thought. And, it is not just fatigue that can impede willpower; stress, bad moods, and alcohol also weaken it (Heatherton \& Wagner, 2011).

The benefits of willpower are in doubt in other ways. While resisting temptations is more effective than not resisting, the empirical success of resistance varies considerably across studies conducted in real life. Some studies find that resistance is adequate (Hennecke et al., 2019; Hofmann, Schmeichel, et al., 2012), while others find that it was successful in fewer than half the occasions it was attempted (Milyavskaya et al., in press). What is worse, when looking beyond success or failure in one particular situation, at least one study suggests there is little connection between regularly engaging willpower and making progress on one's goals (Milyavskaya \& Inzlicht, 2017). Despite promises that willpower is one of the keys to goal attainment, in the long-run, people who use it may not be better at meeting their goals than people who don't.

It is not yet clear if willpower is generally effective or not. What seems clear, is that willpower is overrated. There are other, and arguably better, means to reach one's goals; and the people who reach their goals already know it. 


\section{Conflict of Interest and Funding Statements}

The authors certify that they have NO affiliations with or involvement in any organization or entity with any financial interest or non-financial interest in the subject matter discussed in this commentary.

We would like to acknowledge grant support from the Social Sciences and Humanities Research Council of Canada (\#435-2019-0144) and the Natural Sciences and Engineering Research Council of Canada (RGPIN-2019-05280) to Michael Inzlicht. 


\section{References}

Blain, B., Hollard, G., \& Pessiglione, M. (2016). Neural mechanisms underlying the impact of daylong cognitive work on economic decisions. Proceedings of the National Academy of Sciences, 113(25), 6967-6972.

Casey, B. J., Somerville, L. H., Gotlib, I. H., Ayduk, O., Franklin, N. T., Askren, M. K., Jonides, J., Berman, M. G., Wilson, N. L., Teslovich, T., Glover, G., Zayas, V., Mischel, W., \& Shoda, Y. (2011). Behavioral and neural correlates of delay of gratification 40 years later. Proceedings of the National Academy of Sciences, 108(36), 14998-15003.

Converse, B. A., Juarez, L., \& Hennecke, M. (2019). Self-control and the reasons behind Our goals. Journal of Personality and Social Psychology, 116(5), 860-883.

de Ridder, D. T. D., Lensvelt-Mulders, G., Finkenauer, C., Stok, F. M., \& Baumeister, R. F. (2012). Taking stock of self-control: a meta-analysis of how trait self-control relates to a wide range of behaviors. Personality and Social Psychology Review, 16(1), 76-99.

Friese, M., Loschelder, D. D. D., Gieseler, K., Frankenbach, J., \& Inzlicht, M. (2019). Is Ego Depletion Real? An Analysis of Arguments. Personality and Social Psychology Review, 23(2), 107-131.

Fujita, K. (2011). On conceptualizing self-control as more than the effortful inhibition of impulses. Personality and Social Psychology Review: An Official Journal of the Society for Personality and Social Psychology, Inc, 15(4), 352-366.

Galla, B. M., \& Duckworth, A. L. (2015). More than resisting temptation: Beneficial habits mediate the relationship between self-control and positive life outcomes. Journal of Personality and Social Psychology, 109(3), 508-525.

Heatherton, T. F., \& Wagner, D. D. (2011). Cognitive neuroscience of self-regulation failure. Trends in Cognitive Sciences, 15(3), 132-139.

Hennecke, M., Czikmantori, T., \& Brandstätter, V. (2019). Doing Despite Disliking: Selfregulatory Strategies in Everyday Aversive Activities. European Journal of Personality, 33(1), 104-128.

Hill, P. L., Nickel, L. B., \& Roberts, B. W. (2014). Are You in a Healthy Relationship? Linking Conscientiousness to Health via Implementing and Immunizing Behaviors. Journal of Personality, 82(6), 485-492.

Hockey, G. R. J. (2013). The Psychology of Fatigue. Cambridge Univerity Press.

Hofmann, W., Baumeister, R. F., Förster, G., \& Vohs, K. D. (2012). Everyday temptations: An experience sampling study of desire, conflict, and self-control. Journal of Personality and Social Psychology, 102(6), 1318-1335.

Hofmann, W., Schmeichel, B. J., \& Baddeley, A. D. (2012). Executive functions and selfregulation. Trends in Cognitive Sciences, 16(3), 174-180.

Inzlicht, M., Werner, K. M., Briskin, J. L., \& Roberts, B. W. (2021). Integrating Models of SelfRegulation. Annual Review of Psychology, 72(1), annurev-psych-061020-105721.

Lin, H., Saunders, B., Friese, M., Evans, N. J., \& Inzlicht, M. (2020). Strong Effort Manipulations Reduce Response Caution: A Preregistered Reinvention of the EgoDepletion Paradigm. Psychological Science, 31(5), 531-547.

Ludwig, R. M., Srivastava, S., \& Berkman, E. T. (2019). Predicting Exercise With a Personality Facet: Planfulness and Goal Achievement. Psychological Science, 30(10), 1510-1521.

Ludwig, R. M., Srivastava, S., Berkman, E. T., \& Donnellan, B. (2018). Planfulness: A ProcessFocused Construct of Individual Differences in Goal Achievement. Collabra: Psychology, 
4(1), 1-18.

Mackworth, N. H. (1948). The Breakdown of Vigilance during Prolonged Visual Search. Quarterly Journal of Experimental Psychology, 1(1), 6-21.

Milyavskaya, M., \& Inzlicht, M. (2017). What's So Great About Self-Control? Examining the Importance of Effortful Self-Control and Temptation in Predicting Real-Life Depletion and Goal Attainment. Social Psychological and Personality Science, 8(6), 603-611.

Milyavskaya, M., Inzlicht, M., Hope, N., \& Koestner, R. (2015). Saying "No" to Temptation: Want-to Motivation Improves Self-Regulation by Reducing Temptation Rather Than by Increasing Self-Control. Journal of Personality and Social Psychology, 109(4), 677-693.

Milyavskaya, M., Saunders, B., \& Inzlicht, M. (in press). Self-control in daily life: Prevalence and effectiveness of diverse self-control strategies. Journal of Personality.

Mischel, W., Shoda, Y., \& Rodriguez, M. (1989). Delay of gratification in children. Science, 933-938.

Moffitt, T. E., Arseneault, L., Belsky, D., Dickson, N., Hancox, R. J., Harrington, H., Houts, R., Poulton, R., Roberts, B. W., Ross, S., Sears, M. R., Thomson, W. M., \& Caspi, A. (2011). A gradient of childhood self-control predicts health, wealth, and public safety. Proceedings of the National Academy of Sciences of the United States of America, 108(7), 2693-2698.

Roberts, B. W., Lejuez, C., Krueger, R. F., Richards, J. M., \& Hill, P. L. (2014). What is conscientiousness and how can it be assessed? Developmental Psychology, 50(5), 13151330.

Ryan, R. M., \& Deci, E. L. (2000). Self-determination theory and the facilitation of intrinsic motivation, social development, and well-being. The American Psychologist, 55(1), 68-78.

Schneider, I. K., Gillebaart, M., \& Mattes, A. (2019). Meta-analytic evidence for ambivalence resolution as a key process in effortless self-control. Journal of Experimental Social Psychology, 85.

Tangney, J. P., Baumeister, R. F., \& Boone, A. L. (2004). High Self-Control Predicts Good Adjustment, Less Pathology, Better Grades, and Interpersonal Success. Journal of Personality, 72(April 2004), 271-324.

Watts, T. W., Duncan, G. J., \& Quan, H. (2018). Revisiting the Marshmallow Test: A Conceptual Replication Investigating Links Between Early Delay of Gratification and Later Outcomes. Psychological Science, 29(7), 1159-1177. 